\title{
Association of disproportionate growth of fetal rats in late gestation with raised systolic blood pressure in later life
}

\author{
S. C. Langley-Evans, D. S. Gardner and A. A. Jackson \\ Department of Human Nutrition, University of Southampton, Bassett Crescent East, \\ Southampton, SO16 7PX, UK
}

\begin{abstract}
In human populations, patterns of disproportionate fetal growth are associated with cardiovascular disease in later life. Protein restriction of pregnant rats is known to impair fetal growth and is also associated with increased systolic blood pressure in later life. Growth of fetuses exposed to maternal low protein diets was found to be accelerated between day 14 and day 20 of gestation, but this growth appeared to falter in late gestation, resulting in low or normal birthweights. Placental growth was also accelerated by protein restriction. Day 20 fetuses from rats fed low protein diets were heavier but had proportionally smaller brains than did control fetuses. These animals were also longer in proportion to body mass. Between day 20 and full term (day 22), growth of the brain was spared at the expense of the trunk and at birth, pups exposed to low protein were short in relation to body mass. At weaning, rats exposed to low protein diets in utero had significantly higher systolic blood pressure relative to control animals. These data indicate that increased blood pressure in rats is linked to disproportionate patterns of growth in middle and late gestation.
\end{abstract}

\section{Introduction}

In the human population, metabolic abnormalities underlying coronary heart disease, hypertension and diabetes are associated with undernutrition of the fetus in utero (Barker et al., 1993a). Undernourished fetuses demonstrate patterns of growth dependent upon the timing of the nutritional restriction (Barker, 1994). The fetus undernourished in early gestation will be proportionately small at birth (Barker, 1994). Mid-gestation and late-gestation undernutrition result in disproportionate patterns of growth, each associated with different pathologies in adulthood. The fetus undernourished in mid-gestation is born with a low body mass and is thin in proportion to body mass (Divon et al., 1986). Such an individual will have significantly higher risk of developing non-insulin-dependent diabetes, hypertension and coronary heart disease (Barker, 1994). The individual undernourished in late gestation may be born at a normal body mass but will be short in relation to body mass. In this instance, brain growth has been spared at the expense of the trunk. Small abdominal circumference at birth, an indicator of impaired fetal liver growth, when in conjunction with a low or average birthweight, is associated with increased risk of cardiovascular mortality and increased circulating fibrinogen concentrations, which predict cardiovascular pathology (Barker et al., 1995; Martyn et al., 1995).

These observations in the human population, representing the 'Barker hypothesis', received support from animal experiments. The feeding of low protein diets to pregnant rats is

Received 11 September 1995. associated with higher blood pressure (Langley and Jackson, 1994; Langley-Evans et al., 1994a), altered glucose metabolism (Snoeck et al., 1990; Dahri et al., 1991; Langley-Evans et al., 1994b), insulin resistance (Dahri et al., 1991; Pickard et al,, in press) and increased adiposity in the resulting offspring (McCarthy et al., 1994). The findings of the animal studies mirror the Barker hypothesis in its simplest form, in that low body mass at birth and increased placental mass result from protein restriction in pregnancy in rats (Langley-Evans, 1994). As yet, there is no evidence to link disproportionate growth of rat fetuses in utero with later cardiovascular changes. In this study, patterns of fetal and placental growth were examined in rats fed diets of different protein content.

\section{Materials and Methods}

\section{Animals}

All animal procedures were performed, under licence, in accordance with the Home Office Animal Act. A total of 136 virgin female Wistar rats (200-225 g) were used in the studies. All animals were housed individually in wire mesh cages, maintained at $24^{\circ} \mathrm{C}$ on a $12 \mathrm{~h}$ light cycle. Rats were given free access to drinking water and either a control diet ( $18 \%$ casein), or a low protein diet ( $9 \%$ casein) (Table 1). The diets were isocaloric and supplemented with methionine to prevent sulfur deficiency.

After habituation to the purified diets for 14 days, the rats were mated; and they remained on the diets throughout the mating period (1-6 days). During the mating period, the 
Table 1. Composition of the diets provided

\begin{tabular}{lrc}
\hline \multicolumn{2}{c}{$\mathrm{g}$ per $100 \mathrm{~g}$ diet } \\
\cline { 2 - 3 } Component & $18 \%$ Casein diet & $9 \%$ Casein diet \\
\hline & & \\
Casein & 21.3 & 9.0 \\
Sucrose & 5.0 & 24.3 \\
Cellulose fibre & 42.5 & 5.0 \\
Cornstarch & 0.5 & 48.5 \\
Vitamin mix AIN-76 & 2.0 & 0.5 \\
Mineral mix AIN-76 & 10.0 & 2.0 \\
Maize oil & 0.2 & 10.0 \\
Choline chloride & 0.5 & 0.2 \\
Methionine & & 0.5 \\
\hline
\end{tabular}

Diets were dried for $48 \mathrm{~h}$ at $60^{\circ} \mathrm{C}$, and provided to the animals as balls weighing $60-100 \mathrm{~g}$. AIN-76 mixes, casein, cellulose and cornstarch were purchased from Special Diet Services, Cambridge, UK.

animals were checked three times in every $24 \mathrm{~h}$ and the observation of a plug on the floor of the cage was used to confirm conception. The next day was considered day $I$ of pregnancy. During pregnancy the rats remained on the purified diets. A proportion of pregnancies were terminated before full term (day 22), on day $12,14,16,18$ or 20 . The remaining animals were allowed to give birth and were immediately transferred to a standard laboratory chow diet (CRMX, Special Diet Services, Cambridge, UK). Litters were restricted to a maximum of eight pups, as reported by Langley-Evans et al. (1994a), and weaned at 4 weeks of age.

\section{Termination of pregnancies}

Pregnant rat dams were killed by cervical dislocation and the uteri excised. Placentae and fetuses were dissected out and cleared of membranes and maternal tissue, before accurate weighing. Day 12 and 14 fetuses were dissected from the uterus under a binocular microscope. Fetuses of this age were killed by fixing in formalin, while older fetuses were decapitated. Day 20 fetuses and term neonates were dissected and brain, lung and liver masses determined.

\section{Determination of systolic blood pressure}

Blood pressure was measured in weanling rats (4 weeks old) using a tail cuff method, as described by Langley-Evans and Jackson (1995).

\section{Statistical analysis}

All data are presented as means \pm SEM. Statistical analysis was performed using a Student's $t$ test for unpaired data. A probability of $5 \%$ or less was accepted as significant.

\section{Results}

In an initial study, 46 rats fed the control diet and 58 fed the low protein diet were mated. Considering both full term and terminated pregnancies, litter size was found to be similar in both dietary groups (control, $13.6 \pm 0.6$ pups per litter; low protein, $13.2 \pm 0.5$ pups per litter). The number of resorption sites noted in terminated pregnancies was also unaltered by feeding of low protein during pregnancy (control, $1.5 \pm 0.4$ sites per litter; low protein, $1.7 \pm 0.4$ sites per litter). Significant differences were noted, however, between the masses of fetuses from the two groups (Table 2). Fetal mass was not altered by the maternal low protein diet at day 12 or day 16 of gestation. At day 14, however, fetuses from the low protein group were significantly heavier than control fetuses. Significantly heavier fetuses were also obtained from dams fed the low protein diet on days 18 and 20 of gestation. At full term, the low protein diet group gave birth to pups that were of significantly lower mass than control animals. Pups in the control group had increased body mass by approximately $90 \%$ over the last 2 days of gestation, while the pups of the low protein diet fed dams had increased mass by only $70 \%$.

Placental growth was also modulated by maternal diet (Table 2). On day 14, as with fetal mass, placentae of rats fed the low protein diet were significantly heavier, relative to controls. On day 16, however, the placentae of the low protein group were significantly lighter in the control group. At day 18, placental masses were similar in the two groups of rats. By day 20, placentae of the dams fed low protein were again significantly heavier $(3 \%)$ than those in the control group. It was not possible to obtain placentae from full term pregnancies.

The observation of increased fetal and placental mass in the low protein group was again noted when a second set of five dams fed each diet was killed on day 20 of pregnancy (Table 3). In this study, the nose-anal lengths of the fetuses and the masses of brain, liver and lungs were recorded. Fetuses exposed to low protein were found to be significantly longer than control fetuses. The body mass:length ${ }^{3}$ ratio provides a measure of body composition and proportions (Bernardis and Patterson, 1968) and suggested that, at this age, the fetuses of dams fed the low protein diet were longer in proportion to body mass than control fetuses. Brains, livers and lungs were significantly heavier in the fetuses exposed to low protein, but when the masses of these organs were expressed as a percentage of body mass, lungs and livers were found to be in proportion to body mass. The brains of the fetuses exposed to low protein were, however, proportionately small relative to brains of control fetuses.

The body masses of full term pups born to a further set of five dams fed each diet were found to be similar, regardless of maternal diet (Table 4). Nose-anal length at birth was also unaltered by prenatal dietary experience. The body mass:length ${ }^{3}$ ratio, however, was significantly greater in the offspring of the dams fed the low protein diet. This finding suggests that these pups were short in relation to body mass. Liver, lung and brain masses were similar in the two groups of neonates, both in terms of absolute and relative mass. When compared with day 20 fetuses, all these organs had significantly increased in size. Between day 20 and term, brain mass had increased by $54 \%$ in the control group and $42 \%$ in the low protein group (Fig. 1). In control rats, lung and liver masses had increased by $42 \%$ and $34 \%$, respectively, over the last 2 days of gestation. In rats fed low protein, however, the growth of these 
Table 2. Fetal and placental masses of rats between day 12 of gestation and birth

\begin{tabular}{lrrrrr}
\hline \multirow{2}{*}{$\begin{array}{l}\text { Gestational age } \\
\text { (days) }\end{array}$} & \multicolumn{2}{c}{ Fetal mass $(\mathrm{mg})$} & & \multicolumn{2}{c}{ Placental mass $(\mathrm{mg})$} \\
\cline { 2 - 3 } \cline { 5 - 6 } & $18 \%$ Casein & $9 \%$ Casein & & $18 \%$ Casein & $9 \%$ Casein \\
\hline 12 & $45 \pm 3$ & $44 \pm 2$ & & $111 \pm 5$ & $102 \pm 5$ \\
14 & $186 \pm 7$ & $280 \pm 23^{*}$ & & $201 \pm 9$ & $250 \pm 15^{*}$ \\
16 & $517 \pm 30$ & $463 \pm 29$ & & $431 \pm 18$ & $337 \pm 7^{*}$ \\
18 & $1839 \pm 19$ & $1999 \pm 60^{*}$ & & $487 \pm 13$ & $473 \pm 7$ \\
20 & $2868 \pm 37$ & $3083 \pm 44^{*}$ & & $518 \pm 7$ & $534 \pm 8^{*}$ \\
Term & $5436 \pm 69$ & $5241 \pm 67^{*}$ & & - & - \\
\hline
\end{tabular}

All data are presented as means \pm SEM for $22-208$ observations from a total of 46 pregnancies in the $18 \%$ casein group and 58 in the $9 \%$ casein group.

*Significantly different from $18 \%$ casein group at the same gestational age $(P<0.05)$.

Table 3. Organ masses and body proportions of day 20 rat fetuses

\begin{tabular}{lccc}
\hline & \multicolumn{2}{c}{ Maternal diet } & \\
Parameter & $18 \%$ Casein & $9 \%$ Casein & $P$ \\
\hline Litter size & $14 \pm 1$ & $11 \pm 2$ & NS \\
Body mass (g) & $2.83 \pm 0.08$ & $3.25 \pm 0.08$ & $<0.0005$ \\
Placental mass (g) & $0.54 \pm 0.01$ & $0.59 \pm 0.02$ & $<0.05$ \\
Nose-anal length (mm) & $35 \pm 1$ & $42 \pm 1$ & $<0.0001$ \\
Brain mass (mg) & $109 \pm 3$ & $122 \pm 3$ & $<0.005$ \\
Liver mass (mg) & $128 \pm 5$ & $152 \pm 6$ & $<0.005$ \\
Lung mass (mg) & $83 \pm 4$ & $105 \pm 3$ & $<0.0001$ \\
Body mass:length & & $0.052 \pm 0.001$ & $<0.05$ \\
Brain mass:body mass & $0.069 \pm 0.001$ & $0.037 \pm 0.001$ & $<0.005$ \\
Liver mass:body mass & $0.043 \pm 0.001$ & $0.047 \pm 0.002$ & $\mathrm{NS}$ \\
Lung mass:body mass & $0.049 \pm 0.001$ & $0.032 \pm 0.001$ & $\mathrm{NS}$ \\
\hline
\end{tabular}

All data are means \pm SEM for $n=72$ ( $18 \%$ casein) or $n=65$ ( $9 \%$ casein) observations. Five pregnant rats fed each diet were killed on day 20 of gestation. NS: not significant.

two organs appeared to be greatly curtailed, the lungs increasing in mass by only $22 \%$ and liver mass by $15 \%$.

At the time of weaning, pups that were exposed to maternal low protein diets in utero were significantly heavier (11\%) than controls (Table 5). The increased body mass could not be attributed to increases in mass of liver, lung or brain, all of which were of similar size in the two groups of animals. Animals exposed to low protein had significantly heavier hearts, but when expressed as a percentage of body mass, no difference between the two groups was observed. Control rats and rats exposed to low protein had kidneys of similar size, but renal mass as a percentage of body mass was significantly lower in the low protein group. Systolic blood pressures of weanling rats exposed to low protein diets in utero were significantly higher than those of control animals (Table 5).

\section{Discussion}

Recent epidemiological observations in the British (Barker et al., 1990, 1992, 1993b, 1995; Law et al., 1993), Swedish (Gennser et al., 1988), Indian (Yajnik et al., 1995) and American (Yiu et al., 1994) populations have led to the proposal of the 'Barker hypothesis' (Barker, 1995). It has been suggested that specific patterns of disproportionate fetal growth, which result from fetal undernutrition in middle to late gestation, are associated with metabolic abnormalities, leading to cardiovascular disease. Retrospective studies have demonstrated that asymmetrical growth retardation of the human fetus is a strong predictor of later hypertension, hypercholesterolaemia and death from coronary heart disease (Barker et al., 1993b, 1995).

Support for the hypothesis has come from animal studies in which the feeding of low protein diets during pregnancy results in offspring with higher blood pressures (Langley and Jackson, 1994), increased adiposity (McCarthy et al., 1994), altered glucose metabolism (Langley-Evans et al., 1994b) and insulin resistance (Dahri et al., 1991; Pickard et al., in press). While it is well documented that maternal undernutrition in pregnancy leads to fetal growth retardation in animals (Ariyuki, 1987; Hastings-Robert and Zeman, 1977), the study reported here demonstrates that mild restriction of protein intake leads to higher blood pressure and leads to asymmetrical growth retardation in the resulting offspring. 
Table 4. Organ masses and body proportions of newborn rat pups

\begin{tabular}{lccc}
\hline & & \\
Parameter & $18 \%$ Casein & Maternal diet & $P$ \\
\hline Litter size & $12 \pm 2$ & $9 \%$ Casein & NS \\
Body mass (g) & $5.57 \pm 0.10$ & $13 \pm 2$ & NS \\
Nose-anal length (mm) & $52 \pm 1$ & $5.79 \pm 0.14$ & NS \\
Brain mass (mg) & $168 \pm 7$ & $52 \pm 1$ & NS \\
Liver mass (mg) & $172 \pm 5$ & $173 \pm 5$ & NS \\
Lung mass (mg) & $118 \pm 5$ & $176 \pm 7$ & $<0.0001$ \\
Body mass:length & & $128 \pm 5$ & NS \\
Brain mass:body mass & $0.037 \pm 0.001$ & $0.041 \pm 0.001$ & NS \\
Liver mass:body mass & $0.031 \pm 0.002$ & $0.030 \pm 0.001$ & NS \\
Lung mass:body mass & $0.032 \pm 0.001$ & $0.031 \pm 0.002$ & $0.022 \pm 0.001$ \\
\hline
\end{tabular}

All data are means \pm Sem for $n=59$ (18\% casein) or $n=65$ ( $9 \%$ casein) observations. The offspring of five dams fed each diet were killed within $12 \mathrm{~h}$ of birth. NS: not significant.

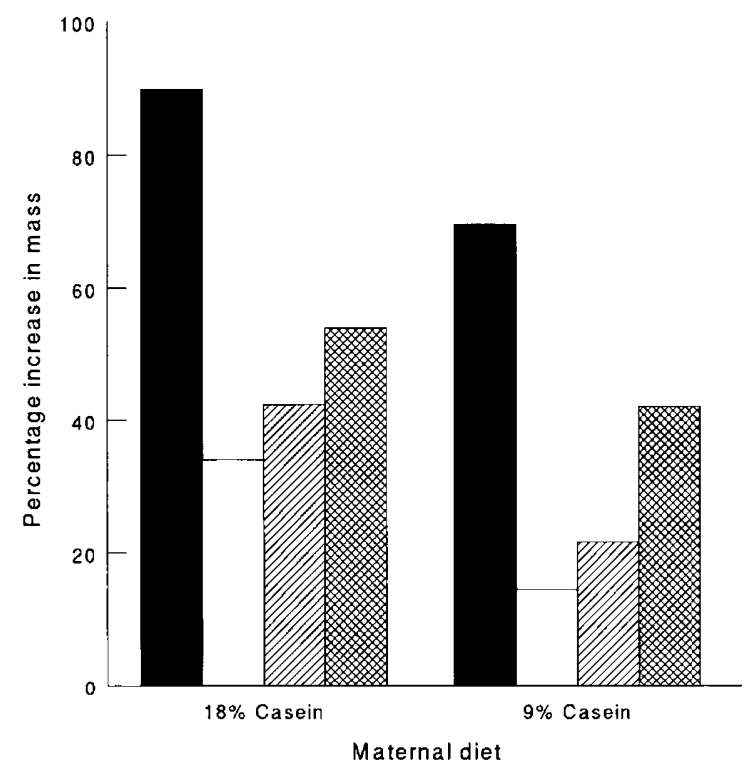

Fig. 1. Growth of fetal organs over the last two days of gestation. The increase in ( $\square$ ) total body mass, $(\square)$ liver mass, ( $\square$ ) lung mass and (ख) brain mass between day 20 of gestation and term is expressed as a percentage of mass at day 20 .

Maternal protein restriction, in addition to increasing blood pressure in weanling offspring, had a number of effects upon the fetus and placenta. It would appear that the growth of the rat fetus in an environment in which the supply of amino acids is limiting is accelerated from mid-gestation until late gestation. Two days before full term, fetuses exposed to low protein were significantly heavier than control fetuses. This pattern of growth differs from an earlier report from our laboratory (Levy and Jackson, 1993), in which feeding of $9 \%$ casein diets retarded fetal growth to day 20 , but enlarged the fetal liver. The present study differs in that larger methionine supplements were given, suggesting that the results described by Levy and Jackson (1993) may be, at least in part, attributable to the effects of a sulfur-limiting diet. As the growth of the rats exposed to low protein diets is accelerated in mid-gestation, an increase in fetal mass before day 20 may have been overlooked in the previous study.

Fetal enlargement from mid- to late gestation, as observed in the low protein group, suggests that an adaptive response in the fetus or placenta allows a more efficient transfer of substrates from mother to fetus, or a more effective utilization of substrate, when amino acids are limiting. This adaptation in the fetus may be achieved through changes in the expression of the insulin-like growth factors (IGFs) and their binding proteins (IGFBPs), which are known to modulate the utilization of glucose and amino acids in fetal tissues (Harding et al., 1994). Insulin-like growth factors and IGFBPs are under nutritional regulation and are sensitive to nutrient intake (Straus et al., 1991; Gallaher et al., 1994; Bauer et al., 1995). The improved growth of the fetuses exposed to low protein in mid-gestation may also be achieved through the increase in placental size noted at day 14 and day 20 of pregnancy, allowing improved oxygen and substrate transfer.

Day 20 fetuses that were exposed to a low protein diet were long in proportion to body mass. These animals may be regarded as correlates of human babies that are thin at birth and subsequently develop high blood pressure and non-insulindependent diabetes (Barker, 1994). It has been proposed that such babies have undergone mid-gestation undernutrition. Whereas these infants are also born small for dates, the thin rat fetuses appeared to continue growing along a different disproportionate trajectory, resembling the effects of undernutrition specifically directed to late gestation. Continuation of maternal undernutrition throughout pregnancy would, therefore, appear to yield patterns of growth that differ from those observed when an insult is applied during critical developmental periods.

Between day 20 and full term, rat fetuses undergo a phase of rapid growth. At this time, body mass is approximately doubled. Continued protein restriction appears to overcome the adaptive response to mid-gestation undernutrition and, in consequence, the fetuses exposed to low protein are born at a slightly lower, or normal, birthweight. Comparing the masses of day 20 and term fetuses suggests that low protein feeding produces a late-gestation growth retardation. During the late-gestation growth phase, control fetuses increased mass 
Table 5. Systolic blood pressure, body mass and organ mass of weanling rat pups

\begin{tabular}{|c|c|c|c|c|c|}
\hline \multirow{3}{*}{$\begin{array}{l}\text { Parameter } \\
\text { Body mass (g) }\end{array}$} & \multicolumn{4}{|c|}{ Maternal diet } & \multirow{3}{*}{$\begin{array}{c}P \\
<0.05\end{array}$} \\
\hline & \multicolumn{2}{|c|}{$18 \%$ Casein } & \multicolumn{2}{|c|}{$9 \%$ Casein } & \\
\hline & 87 & \pm 3 & 97 & \pm 3 & \\
\hline Systolic blood pressure $(\mathrm{mmHg})$ & 109 & \pm 5 & 123 & \pm 4 & $<0.01$ \\
\hline Brain mass $(\mathrm{g})$ & 1.30 & \pm 0.10 & 1.32 & \pm 0.18 & NS \\
\hline Liver mass $(g)$ & 4.16 & \pm 0.83 & 4.61 & \pm 0.95 & NS \\
\hline Heart mass $(\mathrm{g})$ & 0.54 & \pm 0.09 & 0.59 & \pm 0.11 & $<0.01$ \\
\hline Kidney mass $(\mathrm{g})$ & 0.48 & \pm 0.01 & 0.49 & \pm 0.01 & NS \\
\hline Lung mass $(\mathrm{g})$ & 0.85 & \pm 0.10 & 0.88 & \pm 0.18 & NS \\
\hline Brain mass:body mass & 0.015 & \pm 0.001 & 0.014 & \pm 0.001 & NS \\
\hline Liver mass:body mass & 0.048 & \pm 0.002 & 0.048 & \pm 0.002 & NS \\
\hline Heart mass:body mass & 0.006 & \pm 0.001 & 0.006 & \pm 0.001 & NS \\
\hline Kidney mass:body mass & 0.005 & $3 \pm 0.0001$ & 0.005 & \pm 0.0001 & $<0.007$ \\
\hline Lung mass:body mass & 0.010 & \pm 0.001 & 0.009 & \pm 0.001 & NS \\
\hline
\end{tabular}

Ali data are means \pm SEM for $n=43$ ( $18 \%$ casein) or $n=45$ ( $9 \%$ casein) observations. The offspring of six litters born to dams fed each of 18 or $9 \%$ casein diets were weaned at 4 weeks of age and killed on the following day. All litters were restricted to eight pups after birth. NS: not significant.

symmetrically, with similar gains in brain, liver and lung mass. The growth of the low protein group was, however, asymmetric and, while truncal gain was retarded, growth of the brain was spared. This sparing effect was characterized by a larger body mass:length ${ }^{3}$ ratio and a markedly lower increase in body length between day 20 and term, relative to control fetuses. It is apparent that maternal undernutrition in late gestation produces a pattern of disproportionate growth, to accompany the previously observed and here repeated, increases in blood pressure.

It is proposed, within the framework of ideas comprising the Barker hypothesis, that late-gestation undernutrition will result in fetal brain growth being spared at the expense of the trunk (Barker, 1994). This assertion is supported by the present data. However, it was proposed that such individuals in the human population are of lower mass at one year of age, indicating a failure of growth in infancy owing to growth hormone resistance (Fancourt et al, 1976). The rats exposed to low protein diets in utero, however, were of significantly greater mass at weaning, a consistent finding in our laboratory (Langley and Jackson, 1994). This finding may reflect an early onset of adiposity that is perhaps not observed in human infants following intrauterine growth retardation. The main organs of rats exposed to a low protein diet were found to be in proportion to body mass, with the exception of the kidneys, suggesting that excess mass gain between birth and weaning may stem from increased protein deposition in skeletal muscle, or fat deposition in adipose stores, as reported by McCarthy et al. (1994). Adaptive mechanisms were clearly active in mid-gestation and may have had continuing metabolic effects in late gestation. Data from the Dutch Hunger Winter of 1944 suggest that, in men exposed to famine as fetuses in midgestation, rates of obesity in adulthood were markedly increased (Ravelli et al., 1976), a phenomenon replicated in rat studies with low protein diets (Anguita et al., 1992; McCarthy et al., 1994).

The finding of small kidneys in proportion to body mass, in weanling rats exposed to low protein diets in utero, suggests a renal basis for the associated higher blood pressure. This assertion is supported by preliminary evidence from our laboratory. Rats exposed to low protein diets in utero appear to have fewer glomeruli in adult life (S. C. Langley-Evans and S. J. M. Welham, unpublished). Structural changes to the fetal rat kidney are induced by maternal protein restriction (Zeman, 1968). Lower numbers of glomerula (Zeman, 1968), which are also observed in growth retarded human infants (Hinchcliffe et al., 1992), appear to result in impaired renal function (Hall and Zeman, 1968).

It has been proposed that impairment of growth of the liver, the mass of which increased by only $15 \%$ over the last 2 days of gestation in rats exposed to low protein (compared with $34 \%$ in controls) is an early stage in the pathogenesis of coronary heart disease in humans (Barker et al., 1995). Studies in rats suggest that the metabolic zonation of the liver is altered by maternal protein restriction (Desai et al., 1995), and indeed metabolism of glutathione in the liver is radically altered in rats exposed to maternal low protein diets (Langley et al., 1994).

The data presented in this study demonstrate that, as in the human population, the intrauterine environment may programme later hypertension, without consistent changes in birth mass, in rats. Although protein restriction of pregnant rats has been shown to lower resulting birth masses (Langley-Evans et al., 1994a), the rat model of maternal-diet-induced hypertension should not be regarded as a model of intrauterine growth retardation per se. The effect of low protein in gestation is to stimulate disproportionate growth in mid- and late gestation. Feeding low protein diets results in the impairment of peripheral organ growth and this may have important physiological consequences for the initiation of cardiovascular changes. Future studies will examine the effects of nutritional manipulation during specific periods of pregnancy to establish whether patterns of fetal growth associated with human degenerative disease can be replicated in rats.

This work was funded by the Wellcome Trust (Grant no. 043034/ Z/94/Z/MS/PK) and the Medical Research Council (Grant no. 
G9411331). The assistance of P. Collins in collecting day 12 rat embryos is gratefully acknowledged.

\section{References}

Anguita RM, Sigulem DM and Sawaya AL (1992) Intrauterine food restriction is associated with obesity in young rats Journal of Nutrition 123 1421-1428

Ariyuki F (1987) Growth retardation in rat fetuses by maternal fasting and massive doses of ergocalciferol Journal of Nutrition $117342-348$

Barker DJP (1994) Mothers, Babies and Later Disease. British Medical Journal Books, London

Barker DJP (1995) Fetal origins of coronary heart disease British Medical Journal 311 17I-174

Barker DJP, Bull AR, Osmond C and Simmonds SJ (1990) Fetal and placental size and risk of hypertension in later life British Medical Journal 301 259-262

Barker DJP, Meade TW, Fall CHD, Lee A, Osmond C, Phipps K and Stirling Y (1992) Relation of fetal and placental growth to plasma fibrinogen and factor VII concentrations in adult life British Medical Journal 304 148-152

Barker DJP, Gluckman PD, Godfrey KM, Harding JE, Owens JA and Robinson JS (1993a) Fetal nutrition and cardiovascular disease in later life Lancet $\mathbf{3 4 1}$ 938-941

Barker DJP, Martyn CN, Osmond C, Hales CN and Fall CHD (1993b) Growth in utero and serum cholesterol concentrations in adult life British Medical Journal 307 1524-1527

Barker DJP, Martyn CN, Osmond C and Wield GA (1995) Abnormal Jiver growth in utero and death from coronary heart disease British Medical Journa! $310703-704$

Bauer MK, Breier BH, Harding JE, Veldhuis JD and Gluckman PD (1995) The fetal somatotrophic axis during long term maternal undernutrition in sheep: evidence for nutritional regulation in utero Endocrinology 136 1250-1257

Bernadis LL and Patterson BD (1968) Correlation between "Lee Index" and carcass fat content in weanling and adult female rats with hypothalamic lesions Journal of Endocrinology 40 527-528.

Dahri S, Snoeck A, Reussens-Billens B, Remacle C and Hoet JJ (1991) Islet function in offspring of mothers on low protein diets during gestation Diabetes 40 (Supplement 2) 115-120

Desai M, Crowther NJ, Ozanne SE, Lucas A and Hales CN (1995) Adult glucose and lipid metabolism may be programmed during fetal life Biochemical Society Transactions 23 331-335

Divon MY, Chamberlain PF, Sipos L, Mannind FA and Platt LD (1986) Identification of small for gestational age fetus with the use of gestational age-independent indices of fetal growth American Journal of Obsterrics and Gynecology 155 1197-1201

Fancourt R, Campbell S, Harvey D and Norman AP (1976) Follow-up study of small for dates babies British Medical Joumal i 1435-1437

Gallaher BW, Oliver MH, Eichorn K, Kessler U, Kiess W, Harding JE, Gluckman PD and Breier BH (1994) Circulating insulin like growth factor I and II/mannose 6-phosphate receptor and insulin-like growth factor binding proteins in fetal sheep plasma are regulated by glucose and insulin European Journal of Endocrinology 131 398-404

Gennser G, Rymark P and Isberg PE (1988) Low birth weight and risk of high blood pressure in adulthood British Medical Journal 296 1498-1500

Hall SM and Zeman FJ (1968) Kidney function of the progeny of rats fed a low protein diet Journal of Nutrition 95 49-56

Harding JE, Liu L, Evans PC and Gluckman PD (1994) Insulin-like growth factor I alters feto-placental protein and carbohydrate metabolism in fetal sheep Endocrinology 134 1509-1514
Hastings-Roberts MM and Zeman FJ (1977) Effect of protein deficiency, pair feeding or diet supplementation on maternal, fetal and placental growth in rats Journal of Nutrition $107973-982$

Hinchcliffe SA, Lynch MRJ, Sargent PH, Howard CV and van Zelzen D (1992) The effect of intrauterine growth restriction on the development of renal nephrons British Journal of Obstetrics and Gynaecology 99 296-301

Langley SC and Jackson AA (1994) Increased systolic blood pressure in adult rats induced by fetal exposure to maternal low protein diets Clinical Science $86 \quad 217-222$

Langley SC, Seakins M, Grimble RF and Jackson AA (1994) The acute phase response of adult rats is altered by in utero exposure to maternal low protein diets Journal of Nutrition 124 1588-1596

Langley-Evans SC (1994) Early life origins of hypertension: a rat model British Nutrition Foundation Bulletin 19 (Supplement) 69-77

Langley-Evans SC and Jackson AA (1995) Captopril normalises systolic blood pressure in rats with hypertension induced by fetal exposure to maternal low protein diets Comparative Biochemistry and Physiology 110A 223-228

Langley-Evans SC, Phillips GJ and Jackson AA (1994a) In utero exposure to maternal low protein diets induces hypertension in weanling rats, independently of maternal blood pressure changes Clinical Nutrition 13 319-324

Langley-Evans SC, Browne RF and Jackson AA (1994b) Altered glucose tolerance in rats exposed to maternal low protein diets in utero Comparative Biochemistry and Physiology 109A 223-229

Law CM, de Swiet M, Osmond C, Fayers PM, Barker DJP, Cruddas AM and Fall CHD (1993) Initiation of hypertension in utero and its amplification throughout life British Medical Journal $306 \quad 24-27$

Levy $\mathbf{L}$ and Jackson AA (1993) Modest restriction of dietary protein during pregnancy in the rat: fetal and placental growth Journal of Developmental Physiology 19 I13-118

McCarthy HD, Pickard C, Speed J and Jackson AA (1994) Sexual dimorphism of macronutrient selection and regional adipose tissue accumulation following in utero exposure to maternal low protein diets Proceedings of the Nutrition Society $53172 \mathrm{~A}$

Martyn CN, Meade TW, Stirling Y and Barker DJP (1995) Plasma concentrations of fibrinogen and factor VII in adult life and their relation to intrauterine growth British Journal of Haematology 89 142-146

Pickard CL, McCarthy HD, Browne RF and Jackson AA Altered insulin response to a glucose load in rats following exposure to a low protein diet in utero Proceedings of the Nutrition Society (in press)

Ravelli G.P, Stein ZA and Susser MW (1976) Obesity in young men after famine exposure in utero and early infancy New England Journal of Medicine $295 \quad 349-353$

Snoeck A, Remacle C, Reusens B and Hoet JJ (1990) Effect of a low protein diet during pregnancy on the fetal rat endocrine pancreas Biology of the Neonate 57 107-118

Straus DS, Ooi GT, Orlowski CC and Rechlo MM (1991) Expression of the genes for insulin-like growth factor I (IGF-I), IGF II and IGF binding proteins -1 and -2 in fetal rat under conditions of intrauterine growth retardation caused by maternal fasting Endocrinology 128 518-525

Yajnik CS, Fall CHD, Vaidya U, Pandit AN, Bavdekar A, Bhat DS, Osmond C, Hales CN and Barker DJP (1995) Fetal growth and glucose and insulin metabolism in four year old Indian children Diabetic Medicine 12 330-336

Yiu V, Buka S, Zurakowski D, McCormick M, Brenner B and Jabs K (1994) Intrauterine growth retardation (IUGR) as a risk factor for essential hypertension Journal of the American Society for Nephrology 5 S570 22P

Zeman FJ (1968) Effects of maternal protein restriction on the kidney of the newborn young of rats Journal of Nutrition 94 111-117 